\title{
Book review: Das Pedras aos Homens: Tecnologia Lítica na Arqueologia Brasileira (From Stones to Men: Lithic Technology Studies in Brazilian Archaeology)
}

\author{
João Carlos Moreno de Sousa
}

National Museum, Rio de Janeiro Federal University. Quinta da Boa vista, s/n, Rio de Janeiro, Brazil. Email: jcmorenodesousa@gmail.com

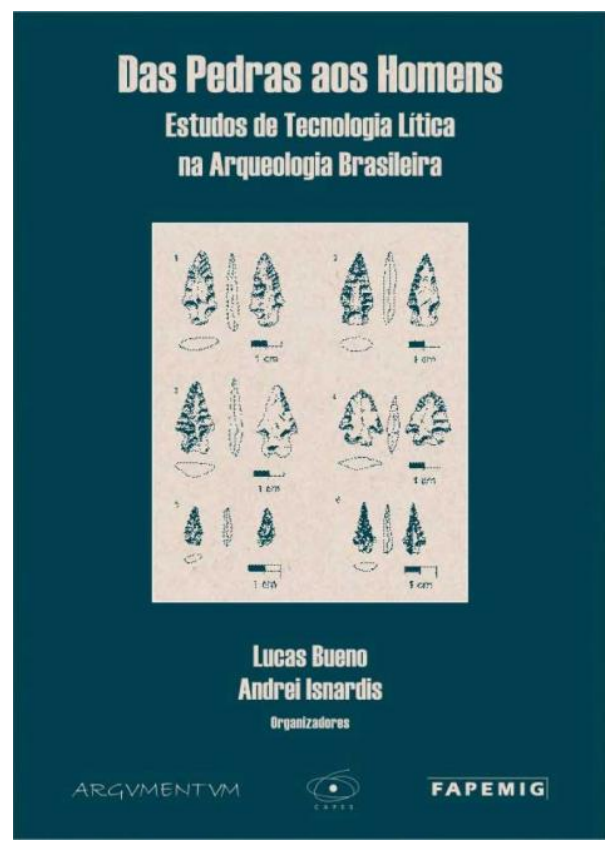

Das Pedras aos Homens: Estudos de Tecnologia Lítica na Arqueologia Brasileira edited by Lucas Bueno and Andrei Isnardis Argvmentvm, 2007, pp. 272. ISBN 978-85-98885-24-7

http://www.finotracoeditora.com.br/livros/IS1008/9788598885247/

The book is the result of a Brazilian symposium which took place in 2007, entitled Lithic technology in Brazil. Theoretical foundations, problems and research perspectives. The symposium brought together some of the most important lithic studies researchers in Brazil at the time. Each researcher wrote a chapter concerning the aims of the symposium.

Published by the School of History, Classics and Archaeology, University of Edinburgh ISSN: 2055-0472. URL: http://journals.ed.ac.uk/lithicstudies/

This work is licensed under a Creative Commons Attribution 2.5 UK: Scotland License. 
In the first chapter, Schmitz informs the readers about lithic studies related to the National Program of Archaeological Research (PRONAPA) that took place between the 1960's and 1970's, and how this pioneering research in Brazil helped our understanding, for the first time, of the Brazilian archaeological context by creating categories of lithic traditions and phases, even though that research didn't have a systematic formation.

Dias, in the second chapter, explains and describes an archaeological category created by PRONAPA researches named Umbu Tradition - supposedly, a lithic tradition of bifacial points that occupied southeastern and southern Brazil. Dias aimed to demonstrate, based on her lithic studies, that there is technological variability between Umbu Tradition sites, and that the tradition and phases concepts do not explain the relationship between artefact variability and cultural behaviour.

Bueno, using his study cases, presents a chapter about technological organization and Design Theory, regarding lithic industries strategies and performance features. Also on the organization subject, Hilbert presents us with an essay that treats the lithic industries as social organization vectors.

Mello presents an article about the technological approach to expedient industries studies, concerned with the general use of a typological approach in Brazilian lithic studies. Rodet \& Alonso, in their chapter, express concern about the lack of homogeneity in Brazilian lithic studies terminology, and also explain the importance of the technological approach, at the same time the description of lithic remains should not only be about their forms and shapes.

Prous, in his chapter, tells us about the importance of experimentation in archaeological studies, pointing out the importance of having contact with the materials and situations which the research may deal with, so that the researcher will have practical knowledge of artefact production and use techniques.

Vilhena-Vialou, in her chapter, demonstrates lithic analysis methods for Pleistocene industries at Central Brazil. The author presents several South American Pleistocene sites and explains the lithic artefact variability at Central Brazilian sites of this same epoch.

Isnardis contributes a chapter regarding the "loneliness" of the lithic industries, aiming to explain that Brazilian archaeologists must highlight their lithic industries interpretations over their artefact categories.

Hoeltz turns her eyes to the South of Brazil presenting its PRONAPA archaeological traditions. The author, using case studies, aims to show that these old typological based approach concepts present weak interpretations when compared to interpretations based on technological analysis.

Finally, Shott, the only foreign author of the book, is concerned with the high French influence on technological studies in Brazil and aims to show Brazilian archaeologists advances in stone-tool reduction analysis in the Anglophone world. His chapter is important in the sense that it shows how different lithic studies "schools" have the same general goals, even though the applied methods are not exactly the same.

Even after eight years since this book was published, it is still a current reference in Brazilian archaeology, at the same time the presented questions are still being discussed, and will still be in discussed for some years from now. As well, this book presents some basic knowledge about lithic studies in a Brazilian archaeological context that will make it an excellent reference for new researchers. Unfortunately, only a few Brazilian lithic studies books have been published in recent decades. Considering this, and the excellent team of authors, Das Pedras aos Homens (From Stones to Men) is, for sure, one of the most important books for Brazilian archaeology of the last decade. 